\begin{tabular}{ll}
\hline \hline MINING AND METALLURGY INSTITUTE BOR & ISSN: 2334-8836 \\
& UDK: 622 \\
\hline \hline
\end{tabular}

UDK: $662.611: 006.82(045)=20$

DOI:10.5937/MMEB1304141K

Vesna Krstić, Biserka Trumić, Mile Bugarin*, Goran Stojanović

\title{
ESTIMATION THE MEASUREMENT UNCERTAINTY OF PHYSICO - CHEMICAL PROPERTIES OF COALS ACCORDING TO ISO 17025
}

\begin{abstract}
One of the important elements for addressing the requirements of international Standard ISO/IEC 17025:2006, specifically set forth in paragraph 5.4.6.2, is to assess the uncertainty of testing and/or calibration. For determination the coal technical analysis uncertainty (moisture, ash, volatiles and combustible substances, c-fix, total sulfur, gross calorific value and net calorific value), the certified reference materials (CRM) benzoic acid (Ref.: 33045 and Ref.: C723, Id. No.: 32430 00) and coal tags GBW 11107k were used. Potential laboratory reference material (RM) was also used for comparison the measurement results and uncertainty in order that, after sufficient number of measurements and statistical analysis, could be used as a laboratory RM. The results showed that both CRM and selected potential laboratory RM could be successfully applied to determine the uncertainty of technical coal analysis, what is significantly cheaper for laboratory work, and in accordance with Standard ISO 17025 .
\end{abstract}

Keywords: CRM, RM, Benzoic acid, Uncertainty, Nordtest, Eurachem, Coal, Technical Analysis.

\section{INTRODUCTION}

Coal is a solid fuel, which dates from the ancient times. For a complete analysis of coal, sample should be carefully sampled and prepared in order to obtain more precise results. Standardized methods are means that allows repeatability and reproducibility of results. In the case of coals, first of all it is important to determine the amount of available energy and relationship of combustible substances to noncombustible parts of fuel, while determination the chemical analysis of coal is not always necessary for the user.

Technical analysis of coals is actually determination of moisture, ash, combus tible and volatile matter, coke residue, C-fix, total sulfur and gross and net calorific values. For technical analysis of coal, the analytical samples, or samples prepared with specific grain size distribution composition are used. Chemical analysis of coal is related to determining the composition of ash, which includes determination of $\mathrm{SiO}_{2}, \mathrm{BaO}, \mathrm{Fe}_{2} \mathrm{O}_{3}, \mathrm{TiO}_{2}, \mathrm{Al}_{2} \mathrm{O}_{3}$, $\mathrm{CaO}, \mathrm{MgO}, \mathrm{Mn}_{3} \mathrm{O}_{4}, \mathrm{Na}_{2} \mathrm{O}_{3}, \mathrm{SO}_{3}$ and phosphorus.

At the beginning of 1999, the international standard ISO/IEC 17025 was published, which contains the general requirements for the competence of testing and/or calibration laboratory. ISO/IEC 17025 has replaced the previous standards EN 45001 and ISO/IEC Guide 25, that was applied in laboratory work. The last edition of this standard dates from 2006. The application of this standard is important for each laboratory

\footnotetext{
*Mining and Metallurgy Institute Bor, Zeleni bulevar 35, 19210 Bor, Serbia,

e-mail:vesna.krstic@irmbor.co.rs
} 
for the purpose of accreditation and implementation the management systems in their work. A lot of data can be found in the literature on application and importance of this standard [1,2].

In the quality control (QC) of measurement methods, which includes assessment of uncertainty, the reference materials play an important role. Reference material is a material or substance whose one or more values of properties are sufficiently homogeneous and well established that they can be used to calibrate the apparatus, for assessment of measurement method or assigning the evalues to materials. Reference materials can be divided into two groups: certified reference materials (CRM) and laboratory (working) reference materials (RM) [3,4]. CRM is a reference material, accompanied by a certificate, whose one or more values of properties confirmed by procedure that establishes traceability for the exact realization of the unit in which are expressed values of characteristics and for which each certified value, is accompanied with measurement uncertainty, with specified confidence level. $\mathrm{RM}$ is a working laboratory material available in laboratory, characterized by homogeneity and stability of material which can provide the repeatable results, at the same time low-cost and as such are eligible for laboratory. CRM are used for evaluation the uncertainty of measurement, to determine the accuracy and precision of mea-sured results, the range of measurements and other parameters of device. In other words, the quality requirements of ISO 17025 limit the uncertainty of measurement study with acceptable confidence level, taking into account what is feasible within the available laboratory equipment and chemicals.

The uncertainty of measurement results is characterized by an interval in which the exact value is claimed to be with specified confidence level. The result of evaluation of measurement uncertainty should be the best approximation of correct values range.
Within the estimation of measurement uncertainty, there are two concepts:

- NORDTEST (QC model)

- EURACHEM (Full scale model).

The aim of Nordtest principle is to present the most important parameters that contribute to the measurement uncertainty: the bias (inaccuracy) and reproducibility (imprecision) of results, while Eurachem includes all the features that influence the measurement uncertainty.

Due to the requirements of ISO/IEC 17025 for assessment the uncertainty, this paper presents the results of using CRM: benzoic acid Ref.: 33 045, with heat of combustion (26 461 \pm 40 ) $\mathrm{Jg}^{-1}$, (ELINCS-Nr.: 200-618-2), benzoic acid Ref.: C723, heat of combustion (26 456 \pm 8 ) $\mathrm{Jg}^{-1}$, (Id. Nr.: 32430 00 ) and coal mark GBW $11107 \mathrm{~K}$ in order to test the uncertainty of laboratory equipment for technical analysis of coal. Also, for checking the possibi-lity of using laboratory $\mathrm{RM}$ in the future laboratory work, the results were compared using the same equipment under the same conditions and with the same contractor for certified reference materials, and also for potential of laboratory RM.

\section{EXPERIMENTAL PART}

To determine the gross calorific value of coal according to the standard norms [5] the calorimeter, model C5000, IKA Werke from 2008, factory no.: 01.666060, was used. Calorimeter was used at a constant volume according to the adiabatic type bomb calorimeter method. Calorimeter is equipped with a software program IKA @ C5000 Control, Version 2.21, and a bomb calorimeter C5010-01.490589 with the following characteristics: $\mathrm{Ps}=230$ bar, $\mathrm{PT}=330$ bar, TS $=50^{\circ} \mathrm{C}$ and $\mathrm{V}=0.260 \mathrm{~L}$. To determine the net calorific value of coal to the same standard norms, it is necessary to determine the hydrogen content in coal [6]. In that purpose, the elemental analyzer, model "vario MACRO cube" from 2010, manufac- 
turer Elementar Analysensysteme $\mathrm{GmbH}$, was used.

For the determination the moisture in the analytical sample of coal using the methods described in the standard norms [7], the dryer with nitrogen stream, model RVT 500, manufacturer Heraus - Hanau, with temperature and time controller NIGOS, model 1012P, factory no.: 7404617, was used. To determine the ash using the method described in the standard norms [8], volatile matter of coal to the standard norms [9], and total sulfur by the method described in standard norms [10], the annealing furnace, type TR f2, manufacturer Iskra, was used. All weight measurements were carried out on the electronic balance, type "Sartorius BP 61S", manufactured in 2008 with accuracy $0.0001 \mathrm{~g}$. To determine the accuracy of laboratory equipment and evaluation the measurement uncertainty, CRM, benzoic acid powder, manufacturer AlliedSignal Riedel-de Haen, Ref.: 33 045, heat of combustion (26 461 \pm 40 ) $\mathrm{Jg}^{-1}$, (ELINCS-Nr.: 200-618-2), which will be called the BA(1) in this work, also pelleted benzoic acid, IKA Werke manufacturers, Ref.: C723, heat of combustion (26 456 \pm ) Jg $^{-1}$, (Id. Nr.: 32 43000), which will be called the BA(2) and coal combustion heat GBW $11107 \mathrm{~K}$ (27.54 \pm 0.19$) \mathrm{MJkg}^{-1}$ which will be called the GBW, were used. As a potential laboratory RM for technical analysis of coal, the coal named ASSM was used. The technique of known values and comparative research technique were used in studying the results.

\section{RESULTS AND DISCUSSION}

Moisture content of coal is essential for accurate determination the other physical and chemical characteristics of coals. First, the moisture effect is important for determining the coal thermal effect, and also affects the overall fuel efficiency practically. In addition to the results of measurements the moisture, ash, volatile matter, total sulfur, hydrogen, and gross and net calorific values of coal, it is important to evaluate the uncertainty of obtained results. By comparison the experimentally obtained results with the exact values given in the reference material certificate, the method accuracy can be determined. Accuracy refers to a particular analytical result and hence represents a combination of systematic and random errors. Systematic error (bias) is the difference between the average value of a large number of measurement results and the exact value of CRM. For determination the correct values the certified reference materials BA(1), BA(2) and GBW (Table 1) were used.

Table 1 Certified values of Gross Combustion Enthalpy (GCV) of CRM (benzoic acid BA(1) Ref.: 33045 and BA(2) Ref.: C723, and coal $(G B W)$ and their mean values obtained by calorimeter IKA Werke, Model C5000 and bias

\begin{tabular}{|c|c|c|c|}
\hline CRM name & GTV CRM* & $\overline{G T V}$ CRM** & bias \\
\hline $\mathrm{BA}(1)\left(\mathrm{Jg}^{-1}\right)$ & $26461 \pm 40$ & 26503 & 42 \\
\hline $\mathrm{BA}(2)\left(\mathrm{Jg}^{-1}\right)$ & $26456 \pm 8$ & 26465 & -9 \\
\hline $\mathrm{GBW}\left(\mathrm{MJkg}^{-1}\right)$ & $27.54 \pm 0.19$ & 27.54 & 0 \\
\hline \multicolumn{2}{|l}{ GTV CRM $*$ - certified or true values of CRM, $\overline{\text { GTV }}$ CRM $* *$ - mean value of measurement results. } \\
\hline
\end{tabular}

\section{a) Nordtest approach}

To determine the uncertainty of results, theNordtest (1) and Eurachem (2) approach were used.
The Nordtest approach represents a practical approach in evaluation the methods and laboratories measurement uncer 
tainty. This approach aims to present the most important parameters that contribute to the measurement uncertainty, which are:

- Reproducibility (imprecision - random error),

- Bias (deviation - a systematic error).

Two ways for calculation the measurement uncertainty exist within the Nordtest concept:

\section{- Method A}

\section{- Method B}

In method $\mathrm{A}$, combined uncertainty $u_{c}$ (\%), calculated using formula (1). Double value of $u_{c}(\%)$ presents an expanded measurement uncertainty $U(\%)$ with a confidence level of $95 \%$, formula (2).

$$
\begin{aligned}
& u_{c}(\%)=\sqrt{(U(R w))^{2}+(U(\text { Bias }))^{2}} \\
& U(\%)=2 \times u_{c}(\%)
\end{aligned}
$$

Contribution to the uncertainty of reproducibility, $U(R w)$, is determined by assessment of internal-laboratory reproducibility, $R w$, according to formula (3), where $\bar{X}$ represents the average value of measurements, while $S_{R W}$ is internal standard reproducibility calculated as the $S_{R W}=\bar{R} / 1.128(\bar{R}$ mean value range).

$$
R w=\frac{S_{R W}}{\bar{X}} \times 100
$$

Contribution to the uncertainty from bias, $U$ (Bias) (\%), is calculated by formula (4).

$$
U(\operatorname{Bias})(\%)=\sqrt{(\text { Bias })^{2}+\left(\frac{S_{\text {Bias }}}{\sqrt{n}}\right)^{2}+u(\text { Cref })^{2}}
$$

In formula (4), (Bias) from CRM, is calculated by formula (5), while the component of uncertainty the certified nominal value, $u(C r e f)$, is calculated by formula (6). In the formula (4) $S_{\text {Bias }}$ represents a multiple testing of CRM, and $n$ is the number of measurements of CRM. $C I$ in formula 6 is a confidence interval.

$$
\begin{aligned}
& (\text { Bias })=\frac{\bar{X}-T}{T} \times 100 \\
& u(\text { Cref })=\left(100 \times \frac{C I(40)}{1.96}\right) / C R M(26461)
\end{aligned}
$$

Table 2 Statistical analysis of GCV obtained with CRM benzoic acid BA(1) Ref.: 33045 for evaluation the uncertainty by Nordtest concept using methods $A$ and $B$ and BA(2) Ref.: C723 for calibration of calorimeter

\begin{tabular}{|c|c|c|c|c|c|}
\hline \multicolumn{5}{|c|}{ CRM BK (1) } & CRM BK (2) \\
\hline $\begin{array}{c}\mathrm{X}_{1} \\
(\mathrm{~J} / \mathrm{g})\end{array}$ & $\begin{array}{c}\mathrm{X}_{2} \\
(\mathrm{~J} / \mathrm{g})\end{array}$ & $\begin{array}{c}\bar{X} \\
(\mathrm{~J} / \mathrm{g})\end{array}$ & $\begin{array}{c}R=\left|X_{1}-X_{2}\right| \\
(\mathrm{J} / \mathrm{g})\end{array}$ & $\begin{array}{c}r=\left|X_{1}-X_{2}\right| / \bar{X} \times 100 \\
\%\end{array}$ & $\begin{array}{c}\text { Calorimeter calibration } \\
\text { by determination of } \\
\text { water values }\end{array}$ \\
\hline 26716 & 26753 & 26735 & 37 & 0,138 & 10758 \\
\hline 26601 & 26575 & 26588 & 26 & 0,098 & 10745 \\
\hline 26645 & 26698 & 26671 & 53 & 0,199 & 10755 \\
\hline 26609 & 26658 & 26633 & 48 & 0,182 & 10741 \\
\hline 26417 & 26491 & 26454 & 74 & 0,280 & 10732 \\
\hline & & $\begin{array}{c}X \\
=26616\end{array}$ & $\bar{R}=47,7$ & $\bar{r}=0,179$ & $\begin{array}{c}\bar{X}=10746 ; \\
\mathrm{s}=10,57 ; \mathrm{S}_{95 \%}=13,14 \\
\text { RelativeSD }=0,1222869 \%\end{array}$ \\
\hline
\end{tabular}

Table 2 are presents the results of combustion heat for $\mathrm{BA}(1)$, which are used to estimate the measurement uncertainty of calorimeter C5000. Using the formula from
(1) to (4), the results are obtained for combined uncertainty by formula (1), and the expanded uncertainty with a confidence level of $95 \%$, according to formula (2). 
Table 3 Statistical analysis of results of technical analysis parameters using laboratory referent material (RM): (a) using analytical sample of coal ASSM and (b) a dry sample ASSM

\begin{tabular}{|c|c|c|c|c|c|c|c|c|c|}
\hline (a) With a & lytical moi & & & & & & & & \\
\hline Date & $\mathbf{N}^{\circ}$ & $\begin{array}{c}\% \\
\text { Moisture }\end{array}$ & $\begin{array}{c}\% \\
\text { Ash }\end{array}$ & $\begin{array}{c}\% \\
\text { Combustible } \\
\text { materials }\end{array}$ & $\begin{array}{c}\% \\
\text { volatile } \\
\text { materials }\end{array}$ & $\begin{array}{l}\% \\
\text { Coke } \\
\text { rest }\end{array}$ & $\begin{array}{c}\% \\
\text { C-fix }\end{array}$ & $\begin{array}{c}\mathbf{S} \\
(\%)\end{array}$ & $\operatorname{GCV}(\mathrm{J} / \mathrm{g})$ \\
\hline \multirow{3}{*}{$1^{\mathrm{st}}$ month } & 1 & 0.69 & 12.45 & 86.86 & 6.06 & 93.25 & 80.80 & 0.900 & 29430 \\
\hline & 2 & 0.67 & 12.01 & 87.32 & 6.34 & 92.99 & 80.98 & 1.412 & 29564 \\
\hline & 3 & 0.67 & 12.01 & 87.32 & 6.34 & 92.99 & 80.98 & 1.004 & 29802 \\
\hline \multirow{2}{*}{$2^{\text {nd }}$ month } & 4 & 1.14 & 11.86 & 87.00 & 5.64 & 93.22 & 81.36 & 0.976 & 29764 \\
\hline & 5 & 1.16 & 12.76 & 86.08 & 5.75 & 93.09 & 80.33 & 1.089 & 29415 \\
\hline \multirow{2}{*}{$3^{\text {th }}$ month } & 6 & 1.42 & 11.70 & 86.88 & 6.42 & 92.16 & 80.46 & 0.944 & 29656 \\
\hline & 7 & 1.43 & 12.59 & 85.98 & 6.63 & 91.94 & 79.35 & - & 29685 \\
\hline \multirow{4}{*}{$\begin{array}{l}\text { Statistical } \\
\text { processing } \\
\text { of data }\end{array}$} & $\bar{X}$ & 1.026 & 12.20 & 86.78 & 6.17 & 92.81 & 80.61 & 1.054 & 29617 \\
\hline & $\mathrm{S}_{68 \%}$ & 0.345 & 0.401 & 0.544 & 0.365 & 0.53 & 0.653 & 0.186 & 153 \\
\hline & $\mathbf{S}_{95 \%}$ & 0.327 & 0.371 & 0.503 & 0.338 & 0.49 & 0.604 & 0.195 & 142 \\
\hline & RSD \% & & 3.04 & 0.58 & 5.48 & 0.53 & 0.75 & & 0.48 \\
\hline \multicolumn{10}{|c|}{ (b) Dry - no moisture } \\
\hline Date & $\mathbf{N}^{\circ}$ & $\begin{array}{c}\% \\
\text { Moisture }\end{array}$ & $\begin{array}{c}\% \\
\text { Ash }\end{array}$ & $\begin{array}{c}\% \\
\text { Combustible } \\
\text { materials }\end{array}$ & $\begin{array}{c}\% \\
\text { volatile } \\
\text { materials }\end{array}$ & $\begin{array}{c}\% \\
\text { Coke } \\
\text { rest }\end{array}$ & $\begin{array}{c}\% \\
\text { C-fix }\end{array}$ & $\underset{(\%)}{S}$ & $\operatorname{GCV}(J / g)$ \\
\hline \multirow{3}{*}{$1^{\text {st }}$ month } & 1 & - & 12.54 & 87.46 & 6.10 & 93.90 & 81.36 & 0.91 & 20634 \\
\hline & 2 & - & 12.09 & 87.91 & 6.38 & 93.62 & 81.53 & 1.42 & 29763 \\
\hline & 3 & - & 12.09 & 87.91 & 6.38 & 93.62 & 81.53 & 1.01 & 30003 \\
\hline \multirow{2}{*}{$2^{\text {nd }}$ month } & 4 & - & 12.00 & 88.00 & 5.71 & 94.29 & 82.3 & 0.99 & 30107 \\
\hline & 5 & - & 12.91 & 87.09 & 5.82 & 94.18 & 81.27 & 1.10 & 29760 \\
\hline \multirow{2}{*}{$3^{\text {th }}$ month } & 6 & - & 11.87 & 88.13 & 6.51 & 93.49 & 81.62 & 0.96 & 30083 \\
\hline & 7 & - & 12.77 & 87.23 & 6.73 & 93.27 & 80.50 & - & 30116 \\
\hline \multirow{4}{*}{$\begin{array}{l}\text { Statistical } \\
\text { processing } \\
\text { of data }\end{array}$} & $\bar{X}$ & - & 12.32 & 87.68 & 6.23 & 93.77 & 81.44 & 1.065 & 29924 \\
\hline & $\mathrm{S}_{68 \%}$ & - & 0.410 & 0.410 & 0.372 & 0.372 & 0.533 & 0.18 & 199 \\
\hline & $\mathbf{S}_{95 \%}$ & - & 0.379 & 0.379 & 0.344 & 0.344 & 0.493 & 0.97 & 184 \\
\hline & RSD \% & & 3.08 & 0.43 & 5.52 & 0.37 & 0.605 & & 0.61 \\
\hline
\end{tabular}

Table 3(a) presents the experimental measurement results of coal physicalchemical characteristics (moisture, ash, evaporation of matter, total sulfur, hydrogen and gross and net calorific values) using the analytical sample of potential laboratory reference material ASSM, and the results obtained by computation like combustible materials, coke rest of and cfix. The results in Table 3(b) are obtained using computer calculation the results from Table 3 using formula (7), corresponding to dry fuel [18].

$$
S=\frac{\% \text { analitical sample }}{100-\text { moisture }} \times 100
$$

Potential laboratory RM, ASSM was measured three times in duplicate or triplicate for 3 months. Table 3, in addition to the obtained results, also gives the statistical analysis of results, so that for each value, obtained experimentally or computationally, the measurement uncertainty was calculated using the method B of Nordtest concept. According to the method $\mathrm{B}$, the measurement uncertainty is directly determined by standard deviation of reproducibility by formula (8), while the expanded uncertainty is determined in the same way as in the method A of Nordtest, formula (2).

$$
u_{c}(\%)=S R
$$




\section{b) Eurachem approach}

The Eurachem approach or full scale model represents a principle that includes everything affecting the measurement uncertainty of results, and as such provides more accurate range of estimated results than Nordtest. Parameters that contribute to complete estimation the measurement uncertainty of coal technical analysis results are:

1) Sampling of coal and sample handling,

2) Equipment (balance, calorimeter, the normal courts, standard solutions, pipette),

3) Human factors and environment (housing and environmental conditions).

Since the technical analysis of coal is performed with the already-prepared analytical sample, the parameters that contribute most to the measurement uncertainty will be included within the Eurachem principles.
These parameters are expressed in the form of bias and reproducibility of used laboratory equipment, and they are directly related to the human factor. Reproducibility of results in Eurachem concept, $R w$, is the same determined as in Nordtest, using formula (3), while formula (6) is modified and expanded for contribution of human factors to the measurement uncertainty which is reflected in handling of laboratory equipment, laboratory ware and chemicals, which involves the use of scales $-u(m)$, purity reagent $-u(n)$, laboratory glassware $-u(v)$, pipettes $-u(p)$ and calibration of calorimeter - $u(k)$. CRM $\mathrm{BA}(2)$ was used for the C5000 calorimeter calibration, and the standard deviation is given on the basis of water value of calorimeter results, given in Table 2. The result of expanded value $u$ (Cref), is given in Table 4 as the square root sum of squares of all contributions to the measurement uncertainty.

Table 4 The extended value of uncertainty component of certified nominal values $u(C r e f)$ for contributions to scale measurement uncertainty $u(m)$, reagent purity $u(n)$, normal courts $u(c)$, pipette $u(p)$ and CRM BA(2) Ref.: C723 u(k) used for calibration of calorimeter

\begin{tabular}{|c|c|c|c|c|}
\hline \multicolumn{5}{|c|}{ Extended value $\boldsymbol{u}($ Cref $)=\mathbf{0 . 1 2 3 3 5 \%}$} \\
\hline$u(m)$ & $u(n)$ & $u(v)$ & $u(p)$ & $u(k)$ \\
\hline $0,016140 \%$ & $0,000289 \%$ & $0,000585 \%$ & $0,000949 \%$ & $0,122287 \%$ \\
\hline
\end{tabular}

Table 5 presents an overview of measurement uncertainty results of combustion heat for CRM BA(1) and a potential laboratory RM ASSM. The results of mea- surement uncertainty heat of combustion for CRM BA(1) are, for comparison, processed by methods A and B of Nordtest concept.

Table 5 Grain-size distribution, chemical composition and technological parameters of divided flotation of hydrocyclone overflow

\begin{tabular}{|c|c|c|c|c|c|c|}
\cline { 2 - 7 } \multicolumn{1}{c|}{} & \multicolumn{4}{c|}{ Nordtest } & \multicolumn{2}{c|}{ Eurachem } \\
\cline { 2 - 7 } & \multicolumn{2}{c|}{ Method I } & \multicolumn{2}{c|}{ Method II } & \multicolumn{2}{c|}{ Method } \\
\cline { 2 - 7 } & $\boldsymbol{u}_{\boldsymbol{c}}(\boldsymbol{\%})$ & $\boldsymbol{U}(\boldsymbol{\%})$ & $\boldsymbol{u}_{\boldsymbol{c}}(\boldsymbol{\%})$ & $\boldsymbol{U}(\boldsymbol{\%})$ & $\boldsymbol{u}_{\boldsymbol{c}}(\boldsymbol{\%})$ & $\boldsymbol{U}(\boldsymbol{\%})$ \\
\hline 1BK & 0,61 & 1,23 & 0,23 & 0,46 & 0,62 & 1,24 \\
\hline ASSM & - & - & 0,24 & 0,48 & - & - \\
\hline
\end{tabular}


Based on the results of Nordtest concept (Table 5), it is noted that the measurement uncertainty of CRM BA(1) according to the method A provides higher value than method $B$. These values are expected, since method A provides more accurate results of uncertainty than method B whose uncertainty value is directly calculated from the standard deviation using the same values of benzoic acid heat of combustion (Table 1). Measurement the uncertainty of laboratory RM ASSM was determined by method B. The results show that the uncertainty of ASSM has same order as CRM BA(1), and it is therefore possible to use ASSM as a laboratory RM. The results of measurement uncertainty estimation by EURACHEM show greater value than the results of methods A of Nordtest, since the method principle is more demanding, and thus a more complete and accurate.

Table 6 Comparison of results of certified values of CRM physico-chemical characteristics for coal GBW 11 107k, with the results obtained using the laboratory equipment for technical analysis of coal

\begin{tabular}{|l|c|c|}
\cline { 2 - 3 } \multicolumn{1}{c|}{} & \multicolumn{2}{c|}{ CRM GBW } \\
\cline { 2 - 3 } \multicolumn{1}{c|}{} & Certified values & Experimental values \\
\hline GTV $\left(\mathbf{M J k g}^{-\mathbf{1}}\right)$ & $27,54 \pm 0,19$ & $27,54 \pm 0,15$ \\
\hline $\boldsymbol{( \% )}$ Ash & $14,89 \pm 0,08$ & $15,15 \pm 0,23$ \\
\hline$(\boldsymbol{\%})$ Volatile mater & $32,41 \pm 0,39$ & $32,12 \pm 0,76$ \\
\hline$(\boldsymbol{\%}) \mathbf{S}$ total & $0,96 \pm 0,02$ & $0,94 \pm 0,11$ \\
\hline$(\boldsymbol{\%}) \mathbf{H}$ & $4,21 \pm 0,13$ & $4,30 \pm 0,23$ \\
\hline$(\boldsymbol{\%}) \mathbf{C}$ & $68,47 \pm 0,30$ & $68,32 \pm 0,72$ \\
\hline$(\boldsymbol{\%}) \mathbf{N}$ & $1,21 \pm 0.03$ & $1,24 \pm 0,02$ \\
\hline
\end{tabular}

Table 6 presents an overview of certified CRM GBW values in units which are given in the certificate. The experimental results are given in the same units, ensuring traceability of results. Comparing experimental data with the certified values (Table 6), it can be concluded that the obtained experimental values and their estimated uncertainty are of the same order of magnitude as the certificated values. The obtained results confirm the quality system of laboratory for coal technical analysis according to ISO 17025.

\section{CONCLUSION}

Evaluation the measurement uncertainty of laboratory for technical analysis of coal based on requirements of ISO/IEC 17025:2006, was successfully determined using the certified reference materials:
BA(1) Ref.: 33 045, with combustion heat

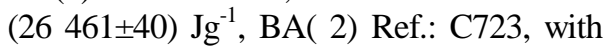
combustion heat (26 456 \pm 8 ) $\mathrm{Jg}^{-1}$ and coal CRM GBW 11 107k, with combustion heat $(27.54 \pm 0.19) \mathrm{MJkg}^{-1}$. Uncertainties of reference materials results were used to determine the uncertainty of laboratory equipment, used for technical analysis of coal. Determined laboratory RM was also used to determine the uncertainty of laboratory equipment and it is proved that it can be a tool that laboratories can use with confidence in evaluation the uncertainty, either as an immediate replacement of CRM, or as working laboratory material. The useful information on possibilities of different methods in determining the measurement uncertainty and different materials used in the laboratory for technical analysis of coal are presented by this way. The results showed that, as certified reference materials, 
also and selected laboratory RM could be applied in evaluation the uncertainty of measurement the technical analysis of coal, which is significantly cheaper for laboratory work than CRM, and in accordance with ISO 17025 standard.

\section{REFERENCES}

[1] International Standards Organization, ISO/IEC 17025:2006, General Requirements for the Competence of Testing and Calibration Laboratories, ISO, 2006.

[2] Jovanović M., Acred. Qual. Assur. 2004, 9, pp. 96-98.

[3] B. M. Simonet, Quality control in qualitative analysis, Trends Anal. Chem. 24 (2005), pp. 525-531.

[4] Hubert Ph.; Chiap P.; Crommen J.; Boulanger B.; Chapuzet E.; Mercier N.; Bervoas-Martin S.; Chevalier P.; Grandjean D.; Lagorce P.; Lallier M.; Laparra M. C.; Laurentie M.; Nivet J. C. Anal. Chim. Acta. 1999, 391, pp. 135-148.

[5] International Standards Organization, ISO/R 1928:1971, Methods of analysis of coal and coke. Determination of gross calorific value by the calorimetric bomb method, and calculation of net calorific value, ISO, Geneva, Switzerland, 1971.
[6] International Standards Organization, ISO/TS 12902:2001, Solid mineral fuels - Determination of total carbon, hydrogen and nitrogen - Instrumental methods, ISO, Geneva, Switzerland, 2001.

[7] International Standards Organization, ISO 589:1981, Methods of analysis of coal and coke. Determination of total moisture in hard coal, ISO, Geneva, Switzerland, 1981.

[8] International Standards Organization, ISO 1171:1981, Methods of analysis of coal and coke. Determination of ash, ISO, Geneva, Switzerland, 1981.

[9] International Standards Organization, ISO 562:1981, Methods of analysis of coal and coke. Determination of the volatile matter content, ISO, Geneva, Switzerland, 1981.

[10] International Standards Organization, ISO 334:1992, Solid mineral fuels Determination of total sulfur - Eschka method, ISO, Geneva, Switzerland, 1992. 


\begin{tabular}{ll}
\hline \hline INSTITUT ZA RUDARSTVO I METALURGIJU BOR & ISSN: 2334-8836 \\
& UDK: 622 \\
\hline \hline
\end{tabular}

Vesna Krstic ", Biserka Trumić, Mile Bugarin", Goran Stojanović

\title{
PROCENA MERNE NESIGURNOSTI FIZIČKO-HEMIJSKIH OSOBINA UGLJEVA PREMA ISO 17025
}

\begin{abstract}
Izvod
Jedan od značajnih elemenata za rešavanje zahteva međunarodnog standarda ISO/IEC 17025:2006, posebno izneta u tački 5.4.6.2, jeste procena merne nesigurnosti laboratorija za ispitivanje. Za određivanje merne nesigurnosti tehničke analize ugljeva (vlage, pepela, sadržaja isparljivih i sagorljivih materija, c-fiks, ukupnog sumpora, gornje i donje toplotne vrednosti), korišćeni su sertifikovani referentni materijali (CRM): benzoeva kiselina i ugalj oznake GBW 11107k. Potencijalni laboratorijski referentni materijal (RM), takođe je korišćen radi upoređivanja rezultata merenja i merne nesigurnosti kako bi se, posle dovoljnog broja merenja i statističke obrade podataka, mogao upotrebiti kao laboratorijski RM. Rezultati su pokazali da se, kako sertifikovani referentni materijali, tako i izabrani potencijalni laboratorijski RM, može uspešno primeniti za određivanje merne nesigurnosti tehničke analize ugljeva, a što je znatno jeftinije za laboratorijski rad, a u saglasnosti je sa standardnom ISO 17025.
\end{abstract}

Ključne reči: CRM, RM, benzoeva kiselina, merna nesigurnost, Nordtest metod, Eurachem metod

\section{UVOD}

Ugalj je čvrsto gorivo koje datira od davnina. Za kompletnu analizu ugljeva, potrebno je pažljivo uzorkovati i pripremiti uzorak kako bi se dobili što precizniji rezultati prilikom analiziranja ugljeva. Standardizovane metode su sredstva koja omogućavaju ponovljivost i reproduktivnost rezultata. Kada se radi o ugljevima, u prvom redu je važno da se odredi količina raspoložive energije, kao i odnos sagorljive supstance prema nesagorljivim delovima goriva, dok određivanje hemijske analize ugljeva nije uvek neophodno za korisnika.

Kada se govori o tehničkoj analizi ugljeva, misli se na određivanje \% vlage uzorka, određivanje \% pepela, \% sagorljivih $\mathrm{i}$ isparljivih materija, \% koksnog ostatka, \% C-fiks, \% ukupnog sumpora i gornje i donje toplotne moći uglja. Za tehničku analizu ugljeva, koriste se analitički uzorci, odnosno uzorci pripremljeni tako da imaju oređeni granulometrijski sastav. Hemijska analiza ugljeva se odnosi na određivanje sastava pepela koji uključuje određivanje $\mathrm{SiO}_{2}$, $\mathrm{BaO}, \mathrm{Fe}_{2} \mathrm{O}_{3}, \mathrm{TiO}_{2}, \mathrm{Al}_{2} \mathrm{O}_{3}, \mathrm{CaO}, \mathrm{MgO}$, $\mathrm{Mn}_{3} \mathrm{O}_{4}, \mathrm{Na}_{2} \mathrm{O}_{3}, \mathrm{SO}_{3} \mathrm{i}$ fosfora.

Početkom 1999. godine objavljen je međunarodni standard ISO/IEC 17025 [1], koji sadrži opšte zahteve za kompetentnost laboratorija za ispitivanje i/ili etaloniranje. ISO/IEC 17025 je zamenio prethodne standarde EN 45001 i ISO/IEC Vodič 25, koji su se primenljivali u radu laboratorija. Poslednje izdanje datira iz 2006. godine. Primena ovog standarda je važna za svaku laboratoriju u cilju akreditacije i u spro-

\footnotetext{
*Institut za rudarstvo i metalurgiju Bor, Zeleni bulevar 35, 19210 Bor, Srbija, e-mail:vesna.krstic@irmbor.co.rs
} 
vođenju sistem menadžmenta u svom radu. O primeni i važnosti ovog standarda može se naći u literaturi [2].

$\mathrm{Za}$ kontrolu kvaliteta (QC) merne metode, što uključuje i procenu merne nesigurnosti, važnu ulogu imaju referentni materijali. Referentni materijal je materijal ili supstanca čije su jedna ili više vrednosti osobina dovoljno homogeni i dobro ustanovljeni da mogu da se koriste za etaloniranje aparata, procenu mernih metoda, ili za pripisivanje vrednosti materijalima. Referentni materijali se mogu svrstati u dve grupe: sertifikovani (overeni) referentni materijali (CRM) i laboratorijski (radni) referentni materijali (RM) [3, 4]. CRM je referentni materijal, praćen uverenjem, čija su jedna ili više vrednosti osobina overene postupkom kojim se uspostavlja sledljivost sa tačnim ostvarenjem jedinice u kojoj se izražavaju vrednosti osobina i za koga je svaka overena vrednost praćena mernom nesigurnošću sa naznačenim nivoom poverenja. Laboratorijski RM je radni materijal sa kojim laboratorija raspolaže, a čije su osnovne karakteristike homogenost materijala i stabilnost koje mogu da obezbede ponovljivost rezultata, a istovremno su jeftini i kao takvi prihvatljivi za laboratoriju. CRM se koriste za procenu merne nesigurnosti, za određivanje tačnosti i preciznosti rezultata merenja, opsega merenja i drugih parametara aparata. Drugim rečima, zahtevi kvaliteta ISO 17025 ograničavaju nesigurnost jedne studije merenja sa prihvatljivim nivoom poverenja, uzimajući u obzir ono što je izvodljivo u okviru raspoložive laboratorijske opreme i hemikalija.

Nesigurnost rezultata merenja karakteriše interval vrednosti za koji se tvrdi da se unutar njega nalazi tačna vrednost, sa specificiranim nivoom poverenja. Rezultat procene merne nesigurnosti treba da bude najbolja aproksimacija opsega tačne vrednosti. U okviru procene merne nesigurnosti postoje dva koncepta:

- NORDTEST (QC model),

- EURACHEM (Full scale model).
Cilj Nordtest principa je da prikaže najvažnije parametre koji doprinose mernoj nesigurnosti: bias (netačnost) i reproduktivnost (nepreciznost) rezultata, dok Eurachem uključuje sve mogućnosti koji utiču na mernu nesigurnost.

Zbog zahteva međunarodnog standarda ISO/IEC 17025 o proceni merne nesigurnosti, ovaj rad prikazuje rezultate korišćenja CRM: benzoeve kiseline Ref.: 33045, toplote sagorevanja $(26461 \pm 40) \mathrm{Jg}^{-1}$, (ELINCS-Nr.: 200-618-2), benzoeve kiseline Ref.: C723, toplote sagorevanja (26456 \pm 8$) \mathrm{Jg}^{-1}$, (Id.Nr.: 32430 00) i uglja oznake GBW11107K u cilju provere merne nesigurnosti opreme laboratorija za tehničku analizu ugljeva. Takođe, radi provere mogućnosti korišćenja laboratorijskog RM u budućem laboratorijskom radu, upoređivani su dobijeni rezultati koristeći istu opremu pod istim uslovima i sa istim izvođačem, kako sertifikovanih referentnih materijala, tako i potencijalnog laboratorijskog RM.

\section{EKSPERIMENTALNI DEO}

Za određivanje gornje toplotne vrednosti ugljeva prema standardnoj normi [5], korišćen je kalorimetar, model C5000, proizvođača IKA Werke iz 2008. godine, sa fabričkim br.: 01.666060. Kalorimetar je korišćen u uslovima pri konstantnoj zapremini po metodi kalorimetarske bombe adiabatskog tipa. Opremljen je softverskim programom IKA ${ }^{\circledR}$ C5000 Control, Version 2.21 i kalorimetarskom bombom C501001.490589 sa sledećim karakteristikama: Ps $=230$ bar, $\mathrm{PT}=330$ bar, $\mathrm{TS}=50^{\circ} \mathrm{C} \mathrm{i}$ $\mathrm{V}=0,260 \mathrm{~L}$. Za određivanje donje toplotne vrednosti uglja prema istoj standardnoj normi, potrebno je odrediti sadržaj vodonika u uglju [6] i za to je korišćen elementarni analizator, model «vario MACRO cube» iz 2010. godine, proizvođača Elementar Analysensysteme GmbH.

$\mathrm{Za}$ određivanje vlage $\mathrm{u}$ analitičkom uzorku uglja prema metodama opisanim u standardnim normama [7], korišćena je 
sušnica u struji azota, model RVT 500, proizvođača Heraus - Hanau, sa temperaturnim i vremenskim regulatorom NIGOS, model 1012P, fabričkim br.: 7404617. Za određivanje pepela prema metodi opisanoj $\mathrm{u}$ standardnoj normi [8], isparljivih materija uglja prema standardnoj normi [9], kao i ukupnog sumpora prema metodi opisanoj u standardnoj normi [10], korišćena je peć za žarenje, tip TR f2, proizvođača Iskra.

Sva merenja masa uzoraka, vršena su na elektronskoj vagi, tip „Sartorius BP 61S“, iz 2008. godine, sa fabričkim brojem 80109868, a koja ima vrednost podeoka $0,0001 \mathrm{~g}$.

$\mathrm{Za}$ određivanje tačnosti laboratorijske opreme i procene merne nesigurnosti korišćeni su CRM, benzoeva kiselina $u$ prahu, proizvođača AlliedSignal Riedel-de Haën, Ref.: 33045, toplote sagorevanja

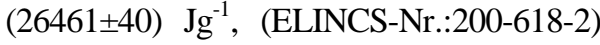
koju ćemo nazvati BK(1), zatim tabletirana benzoeva kiselina, proizvođača IKA Werke, Ref.: C723, toplote sagorevanja (26456 \pm 8$)$ $\mathrm{Jg}^{-1}$, (Id. Nr.: 32430 00) koju ćemo nazvati BK(2) i ugalj GBW 11107K toplote sagorevanja (27.54 \pm 0.19$) \mathrm{MJkg}^{-1}$ koga ćemo nazvati GBW. Kao potencijalni RM laboratorije za tehničku analizu ugljeva, korišćen je ugalj nazvan ASŠM. U ispitivanju rezultata korišćena je tehnika poznatih vrednosti i tehnika uporednog ispitivanja.

\section{REZULTATI I DISKUSIJA}

Sadržaj vlage ugljeva je od presudnog značaja za tačno određivanje ostalih fizičkohemijskih karakteristika ugljeva. U prvom redu, uticaj vlage je važan za određivanje toplotnog efekta uglja, a takođe utiče na celokupno praktično iskorišćenje goriva. Pored dobijenih rezultata merenja vlage, pepela, isparljivih materija, ukupnog sumpora, vodonika i gornje i donje toplotne vrednosti uglja, važno je proceniti i njihove merne nesigurnosti. Poređenjem eksperimentalno dobijenih vrednosti sa tačnim vrednostima datih u sertifikatu referentnog materijala, može se odrediti tačnost metode. Tačnost se odnosi na pojedini analitički rezultat i stoga predstavlja kombinaciju sistematske i slučajne greške. Sistematska greška (bias) predstavlja razliku između srednje vrednosti velikog broja rezultata merenja i tačne vrednosti CRM. Za određivanje tačne vrednosti korišćeni su sertifikovani referentni materijali $\mathrm{BK}(1), \mathrm{BK}(2)$ i GBW, tabela 1.

Tabela 1. Sertifikovane vrednosti gornje toplotne vrednosti (GTV) CRM (benzoeve kiseline BK(1) Ref.: 33045, BK(2) Ref.: C723 i uglja GBW) $i$ njihove srednje vredvosti $\overline{G T V}$ CRM dobijene na kalorimetru IKA Werke, model C5000 sa bias-om.

\begin{tabular}{|c|c|c|c|}
\hline Naziv CRM & GTV CRM* & $\overline{G T V} \mathbf{C R M} \mathbf{M}^{* *}$ & bias \\
\hline $\mathrm{BK}(1)\left(\mathrm{Jg}^{-1}\right)$ & $26461 \pm 40$ & 26503 & 42 \\
\hline $\mathrm{BK}(2)\left(\mathrm{Jg}^{-1}\right)$ & $26456 \pm 8$ & 26465 & -9 \\
\hline GBW $\left(\mathrm{MJkg}^{-1}\right)$ & $27.54 \pm 0.19$ & 27.54 & 0 \\
\hline
\end{tabular}

\section{a) Nordtest pristup}

Za određivanje merne nesigurnosti rezultata korišćeni su:

a) Nordtest pristup $\mathrm{i}$

b) Eurachem pristup.
Nordtest pristup predstavlja praktičan pristup u proceni merne nesigurnosti metode i laboratorije. Cilj ovog pristupa je da 
prikaže najvažnije parametre koji doprinose mernoj nesigurnosti, a to su:

- reproduktivnost (nepreciznost - slučajna greška),

- bias (odstupanje - sistematska greška).

U okviru Nordtest koncepta postoje dve mogućnosti izračunavanja merne nesigurnosti:

- Metod I,

- Metod II.

U okviru metode I, kombinovana nesigurnost, $u_{c}(\%)$, predstavlja kvadratni koren zbira kvadrata doprinosa nesigurnosti od reproduktivnosti, $U(R w)$, i bias-a, $U($ Bias $)$, formula (1). Dvostruka vrednost $u_{c}(\%)$ predstavlja proširenu mernu nesigurnost, $U(\%)$, sa nivoom poverenja od $95 \%$, formula (2).

$$
\begin{aligned}
& u_{c}(\%)=\sqrt{(U(R w))^{2}+(U(\text { Bias }))^{2}} \\
& U(\%)=2 \times u_{c}(\%)
\end{aligned}
$$

Doprinos nesigurnosti od reproduktivnosti, $U(R w)$, određuje se procenom unutar laboratrijske reproduktivnosti, $R w$, prema formuli (3), gde $\bar{X}$ predstavlja srednju vrednost merenja, dok je $S_{R W}$ unutar serijska standardna reproduktivnost izračunata kao $\mathrm{S}_{\mathrm{RW}}=\bar{R} / 1.128(\bar{R}$ je srednja vrednost opsega).

$$
R w=\frac{S_{R W}}{\bar{X}} \times 100
$$

Doprinos nesigurnosti od biasa, U(Bias) (\%), izračunava se prema formuli (4).

$U(\operatorname{Bias})(\%)=\sqrt{(\text { Bias })^{2}+\left(\frac{S_{\text {Bias }}}{\sqrt{n}}\right)^{2}+u(\text { Cref })^{2}}$

U formuli (4), (Bias) iz CRM, izračunava se prema formuli (5), dok se komponenta nesigurnost sertifikovane nominalne vrednosti, $u(C r e f)$, izračunava prema formuli (6). U formuli (4) $S_{\text {Bias }}$ predstavlja višestruko testiranje CRM, a $n$ je broj merenja CRM.

$$
(\text { Bias })=\frac{\bar{X}-T}{T} \times 100
$$

$$
\begin{aligned}
& u(\text { Cref })= \\
& =\left(100 \times \frac{\text { Int.poverenja }(40)}{1.96}\right) / C R M(26461)
\end{aligned}
$$

Tabela 2. Statistička obrada podataka GTV CRM benzoeve kiseline BK(1) Ref.: 33045 za procenu merne nesigurnosti po metodi I i II Nordtest koncepta i BK(2) Ref.: C723 za kalibraciju kalorimetra određivanjem vodene vrednosti.

\begin{tabular}{|c|c|c|c|c|c|}
\hline \multicolumn{5}{|c|}{ CRM BK (1) } & CRM BK (2) \\
\hline $\begin{array}{c}\mathrm{X}_{1} \\
(\mathrm{~J} / \mathrm{g})\end{array}$ & $\begin{array}{c}\mathrm{X}_{2} \\
(\mathrm{~J} / \mathrm{g})\end{array}$ & $\begin{array}{c}\bar{X} \\
(\mathrm{~J} / \mathrm{g})\end{array}$ & $\begin{array}{c}R=\left|X_{1}-X_{2}\right| \\
(\mathrm{J} / \mathrm{g})\end{array}$ & $\begin{array}{c}r=\left|X_{1}-X_{2}\right| / \bar{X} \times 100 \\
\%\end{array}$ & $\begin{array}{c}\text { Kalibracija kalorimetra } \\
\text { odredivanjem vodene } \\
\text { vrednosti }\end{array}$ \\
\hline 26716 & 26753 & 26735 & 37 & 0,138 & 10758 \\
\hline 26601 & 26575 & 26588 & 26 & 0,098 & 10745 \\
\hline 26645 & 26698 & 26671 & 53 & 0,199 & 10755 \\
\hline 26609 & 26658 & 26633 & 48 & 0,182 & 10741 \\
\hline 26417 & 26491 & 26454 & 74 & 0,280 & 10732 \\
\hline & & $\begin{array}{l}X \\
=26616\end{array}$ & $\bar{R}=47,7$ & $\bar{r}=0,179$ & $\begin{array}{c}\bar{X}=10746 ; \\
\mathrm{s}=10,57 ; \mathrm{S}_{95 \%}=13,14 \\
\text { RelativnaSD }=0,1222869 \%\end{array}$ \\
\hline
\end{tabular}

U tabeli 2 su dati rezultati toplote sagorevanja BK(1), koji su korišćeni za određivanje merne nesigurnosti kalorimetra, C5000. Korišćenjem formula od (1) do (4) dobijeni su rezultati kombinovane nesigurnosti prema formuli (1), i proširene merne nesigurnosti sa nivoom poverenja od $95 \%$, prema formuli (2). 
Tabela 3. Statistička obrada rezultata parametara tehničke analize laboratoriskog RM na (a) analitičkom uzorku uglja ASŠM i (b) na suvom uzorku ASŠM.

\begin{tabular}{|c|c|c|c|c|c|c|c|c|c|}
\hline \multicolumn{10}{|c|}{ (a) Sa analitičkom vlagom } \\
\hline Datum & $\begin{array}{c}\text { Br. } \\
\text { merenja }\end{array}$ & $\begin{array}{c}\% \\
\text { vlaga }\end{array}$ & $\begin{array}{c}\% \\
\text { Pepeo }\end{array}$ & $\begin{array}{l}\text { \% Sagor. } \\
\text { Materije }\end{array}$ & $\begin{array}{l}\text { \% Ispar. } \\
\text { Materije }\end{array}$ & $\begin{array}{l}\text { \% Koks. } \\
\text { Ostatak }\end{array}$ & $\begin{array}{c}\% \\
\text { C-fiks }\end{array}$ & $\begin{array}{l}S \\
(\%)\end{array}$ & GTM $(\mathbf{J} / \mathbf{g})$ \\
\hline \multirow{3}{*}{ 1. mesec } & 1 & 0,69 & 12,45 & 86,86 & 6,06 & 93,25 & 80,80 & 0,900 & 29430 \\
\hline & 2 & 0,67 & 12,01 & 87,32 & 6,34 & 92,99 & 80,98 & 1,412 & 29564 \\
\hline & 3 & 0,67 & 12,01 & 87,32 & 6,34 & 92,99 & 80,98 & 1,004 & 29802 \\
\hline \multirow{2}{*}{ 2. mesec } & 4 & 1,14 & 11,86 & 87,00 & 5,64 & 93,22 & 81,36 & 0,976 & 29764 \\
\hline & 5 & 1,16 & 12,76 & 86,08 & 5,75 & 93,09 & 80,33 & 1,089 & 29415 \\
\hline \multirow{2}{*}{ 3. mesec } & 6 & 1,42 & 11,70 & 86,88 & 6,42 & 92,16 & 80,46 & 0,944 & 29656 \\
\hline & 7 & 1,43 & 12,59 & 85,98 & 6,63 & 91,94 & 79,35 & - & 29685 \\
\hline \multirow{4}{*}{$\begin{array}{l}\text { Statistička } \\
\text { obrada } \\
\text { podataka }\end{array}$} & $\bar{X}$ & 1.026 & 12,20 & 86,78 & 6,17 & $\mathbf{9 2 , 8 1}$ & 80,61 & 1,054 & 29617 \\
\hline & $\mathrm{S}_{68 \%}$ & 0,345 & 0,401 & 0,544 & 0,365 & 0,53 & 0,653 & 0,186 & 153 \\
\hline & $\mathbf{S}_{95 \%}$ & 0,327 & $\mathbf{0 , 3 7 1}$ & 0,503 & 0,338 & $\mathbf{0 , 4 9}$ & 0,604 & 0,195 & 142 \\
\hline & rel.stdev.\% & & 3,04 & 0,58 & 5,48 & 0,53 & 0,75 & & 0,48 \\
\hline \multicolumn{10}{|c|}{ (b) Suv - bez vlage } \\
\hline Datum & $\begin{array}{c}\text { Br. } \\
\text { merenja }\end{array}$ & $\begin{array}{c}\% \\
\text { vlaga }\end{array}$ & $\begin{array}{c}\% \\
\text { Pepeo }\end{array}$ & $\begin{array}{c}\text { \% Sagor. } \\
\text { materije }\end{array}$ & $\begin{array}{l}\text { \% Ispar. } \\
\text { materije }\end{array}$ & $\begin{array}{c}\text { \% Koks. } \\
\text { ostatak }\end{array}$ & $\begin{array}{c}\% \\
\text { C-fiks }\end{array}$ & $\begin{array}{c}\mathbf{S} \\
(\%)\end{array}$ & GTM $(\mathbf{J} / \mathbf{g})$ \\
\hline \multirow{3}{*}{ 1. mesec } & 1 & - & 12,54 & 87,46 & 6,10 & 93,90 & 81,36 & 0,91 & 20634 \\
\hline & 2 & - & 12,09 & 87,91 & 6,38 & 93,62 & 81,53 & 1,42 & 29763 \\
\hline & 3 & - & 12,09 & 87,91 & 6,38 & 93,62 & 81,53 & 1,01 & 30003 \\
\hline \multirow{2}{*}{ 2. mesec } & 4 & - & 12,00 & 88,00 & 5,71 & 94,29 & 82,3 & 0,99 & 30107 \\
\hline & 5 & - & 12,91 & 87,09 & 5,82 & 94,18 & 81,27 & 1,10 & 29760 \\
\hline \multirow{2}{*}{ 3. mesec } & 6 & - & 11,87 & 88,13 & 6,51 & 93,49 & 81,62 & 0,96 & 30083 \\
\hline & 7 & - & 12,77 & 87,23 & 6,73 & 93,27 & 80,50 & - & 30116 \\
\hline \multirow{4}{*}{$\begin{array}{l}\text { Statistička } \\
\text { obrada } \\
\text { podataka }\end{array}$} & $\bar{X}$ & - & 12,32 & 87,68 & 6,23 & 93,77 & 81,44 & 1,065 & 29924 \\
\hline & $\mathrm{S}_{68 \%}{ }^{\Lambda}$ & - & 0,410 & 0,410 & 0,372 & 0,372 & 0,533 & 0,18 & 199 \\
\hline & $\mathbf{S}_{95 \%}$ & - & 0,379 & 0,379 & 0,344 & 0,344 & 0,493 & 0,97 & 184 \\
\hline & rel.stdev.\% & & 3,08 & 0,43 & 5,52 & 0,37 & 0,605 & & 0,61 \\
\hline
\end{tabular}

U tabeli 3(a) su dati eksperimentalni rezultati merenja fizičko-hemijskih karakteristika uglja (vlaga, pepeo, isparljive materije, ukupan sumpor, vodonik i gornja i donja toplotna vrednost) korišćenjem analitičkog uzorka laboratorijskog potencijalnog referentnog materijala ASŠM, kao i rezultati dobijeni računskim putem (sagorljive materije, koksni ostatak i c-fiks). Rezultati u tabeli 3(b) su računski dobijeni na suvo gorivo preračunavanjem rezultata tabele 3(a), koristeći formulu (7).

$$
S=\frac{\% \text { analit.uzorka }}{100-\text { vlaga }} \times 100
$$

Potencijalni laboratorijski RM, ASŠM meren je 3 puta u duplikatu ili triplikatu u periodu od 3 meseca. U tabeli 3 je, pored dobijenih rezultata, data i statistička obrada rezultata, tako da je za svaku veličinu, bilo dobijenu eksperimentalno ili računski, izračunata merna nesigurnost koristeći metode II Nordtest koncepta. Prema metodi II, merna nesigurnost se direkno određuje korišćenjem standardne devijacije reproduktivnosti prema formuli (8), dok se proširena nesigurnost određuje na isti način kao i u metodi I Nordtesa, formula (2).

$$
u_{c}(\%)=\mathrm{S}_{\mathrm{R}}
$$

\section{b) Eurachem pristup}

Eurachem pristup ili full scale model predstavlja princip koji uključuje sve ono što utiče na mernu nesigurnost rezultata i kao takav daje tačniji opseg procenjenog rezul- 
tata od Nordtesta. Parametri koji doprinose kompletnoj procenjenoj mernoj nesigurnosti rezultata tehničke analize ugljeva su:

1) Uzorkovanje ugljeva i rukovanje uzorcima,

2) Oprema (vaga, kalorimetar, normalni sudovi, standardni rastvori, pipete),

3) Ljudski faktor i sredina (smeštaj i uslovi okoline).

Obzirom da se u tehničkoj analizi ugljeva radi sa več pripremljenim analitičkim uzorkom, u okviru Eurachem principa biće obuhvaćeni parametri koji najviše doprinose mernoj nesigurnosti. Ovi parametri su izraženi u obliku bias-a i reproduktivnosti korišćene laboratorijske opreme, a koji su direktno povezani sa ljudskim faktorom.
Reproduktivnost rezultata $\mathrm{u}$ Eurachem konceptu, $R w$, određuje se isto kao i $\mathrm{u}$ Nordtestu, korišćenjem formula (3), dok je formula (6) izmenjena i proširena za doprinos mernoj nesigurnosti ljudskog faktora koja se ogleda u rukovanju sa laboratorijskom opremom, laboratorijskim posuđem i hemikalijama, a koja uključuje upotrebu vage - $u(m)$, čistoću reagensa - $u(n)$, normalnog suda $-u(v)$, pipete - $u(p)$ i kalibracije kalorimetra - $u(k)$. Za kalibraciju kalorimetra C5000 korišćen je CRM BK(2), a standardna devijacija je data na osnovu rezultata određivanja vodene vrednosti kalorimetra čiji su rezultati dati u tabeli 2. Rezultat proširene vrednosti $u(C r e f)$, dat je u tabeli 4 kao kvadratni koren zbira kvadrata svih doprinosa mernoj nesigurnosti.

Tabela 4. Proširena vrednost komponente nesigurnosti setifikovane nominalne vrednosti $u(C r e f)$ za doprinos mernoj nesigurnosti vage $u(m)$, čistoće reagensa $u(n)$, normalnih sudova $u(v)$, pipeta $u(p)$ i CRM BK(2) Ref.: C723 u(k) kojim je kalorimetar kalibrisan

\begin{tabular}{|c|c|c|c|c|}
\hline \multicolumn{5}{|c|}{ Proširena vrednost $\boldsymbol{u}($ Cref) $=\mathbf{0 , 1 2 3 3 5 \%}$} \\
\hline$u(m)$ & $u(n)$ & $u(v)$ & $u(p)$ & $u(k)$ \\
\hline $0,016140 \%$ & $0,000289 \%$ & $0,000585 \%$ & $0,000949 \%$ & $0,122287 \%$ \\
\hline
\end{tabular}

U tabeli 5 je dat pregled dobijenih rezultata merne nesigurnosti toplota sagorevanja CRM $B K(1)$ i potencijalnog laboratorijskog RM, ASŠM. Rezultati merne nesi- gurnosti toplota sagorevanja CRM BK(1) su, radi upoređivanja, obrađeni metodama I i II Nordtest koncepta.

Tabela 5. Pregled rezultata kombinovane nesigurnosti uc(\%) i njene proširene vrednosti $U(\%)$ za metode I i II Nordtest koncepta i metode Eurachem.

\begin{tabular}{|c|c|c|c|c|c|c|}
\cline { 2 - 7 } \multicolumn{1}{c|}{} & \multicolumn{4}{c|}{ Nordtest } & \multicolumn{2}{c|}{ Eurachem } \\
\cline { 2 - 7 } & \multicolumn{2}{c|}{ Metoda I } & \multicolumn{2}{c|}{ Metoda II } & \multicolumn{2}{c|}{ Metoda } \\
\cline { 2 - 7 } & $\boldsymbol{u}_{\boldsymbol{c}}(\boldsymbol{\%})$ & $\boldsymbol{U}(\boldsymbol{\%})$ & $\boldsymbol{u}_{\boldsymbol{c}}(\boldsymbol{\%})$ & $\boldsymbol{U}(\boldsymbol{\%})$ & $\boldsymbol{u}_{\boldsymbol{c}}(\boldsymbol{\%})$ & $\boldsymbol{U}(\boldsymbol{\%})$ \\
\hline 1BK & 0,61 & 1,23 & 0,23 & 0,46 & 0,62 & 1,24 \\
\hline ASŠM & - & - & 0,24 & 0,48 & - & - \\
\hline
\end{tabular}

$\mathrm{Na}$ osnovu rezultata Nordtest koncepta, tabela 5, zapaža se da merna nesigurnost CRM BK(1) po metodi I daje veću vrednost od metode II. Ove vrednosti su očekivane, obzirom da metoda I daje preciznije rezultate merne nesigurnosti od metode II čija je merna nesigurnost direktno izračunata iz standardne devijacije korišćenjem iste vrednosti toplote sagorevanja benzoeve kiseline, tabela 1 . Merna 
nesigurnost laboratorijskog RM ASŠM je određena metodom II. Rezultati pokazuju da je merna nesigur-nost ASŠM istog reda veličina kao i CRM BK(1), pa ga je zato moguće koristiti kao laboratorijski RM.
Procena merne nesigurnosti prema Eurachem-u je nešto viša od Metode I Nordtesta, obzirom da je sam princip metode zahtevniji, pa samim tim i kompletniji i tačniji.

Tabela 6. Poređenje rezultata sertifikovanih vrednosti fiziko-hemiskih karakteristika CRM, uglja GBW 11107k, sa rezultaima dobijenim korišćenjem laboratorijske opreme za tehničku analizu uglja.

\begin{tabular}{|c|c|c|}
\hline & \multicolumn{2}{|c|}{ CRM GBW } \\
\hline & Sertifikovane vrednosti & Eksperimentalne vrednosti \\
\hline GTV $\left(\mathbf{M J k g}^{-1}\right)$ & $27,54 \pm 0,19$ & $27,54 \pm 0,15$ \\
\hline (\%) Pepeo & $14,89 \pm 0,08$ & $15,15 \pm 0,23$ \\
\hline (\%) Ispar.mat. & $32,41 \pm 0,39$ & $32,12 \pm 0,76$ \\
\hline (\%) S ukupni & $0,96 \pm 0,02$ & $0,94 \pm 0,11$ \\
\hline$(\%) \mathrm{H}$ & $4,21 \pm 0,13$ & $4,30 \pm 0,23$ \\
\hline$(\%) \mathrm{C}$ & $68,47 \pm 0,30$ & $68,32 \pm 0,72$ \\
\hline$(\%) \mathrm{N}$ & $1,21 \pm 0.03$ & $1,24 \pm 0,02$ \\
\hline
\end{tabular}

U tabeli 6 je dat pregled sertifikovanih vrednosti CRM GBW u jedinicama koje su date u sertifikatu. Eksperimentalni rezultati su dati u istim jedinicama, čime se obezbeđuje sledljivost rezultata. Upoređivanjem eksperimentalnih podataka sa sertifikovanim vrednostima, tabela 6 , kao i rezultata tabele 1 , može se zaključiti da su, kako dobijene eksperimentalne vrednosti tako i njihove procenjene merne nesigurnosti istog reda veličine kao i serifikovane. Dobijeni rezultati potvrđuju kvalitet rada laboratorije za tehničku analizu ugljeva prema standardu ISO 17025.

\section{ZAKLJUČAK}

Procena merne nesigurnosti laboratorije za tehničku analizu ugljeva na osnovu zahteva međunarodnog standarda ISO/IEC 17025:2006, uspešno je određena pomoću sertifikovanih referentnih materijala: BK (1)
Ref.: 33045, toplote sagorevanja (26461 \pm 40$)$ $\mathrm{Jg}^{-1}$, BK (2) Ref.: C723, toplote sagorevanja (26456 \pm 8$) \mathrm{Jg}^{-1}$ i uglja CRM označenog GBW, toplote sagorevanja $(27.54 \pm 0.19)$ $\mathrm{MJkg}^{-1}$. Merne nesigurnosti rezultata referentnih materijala, poslužile su za određivanje merne nesigurnosti laboratorijske opreme koja je korišćena za tehničku analizu ugljeva. Određen laboratorijski RM je takođe korišćen za određivanje merne nesigurnosti laboratorijske opreme i pokazao se kao sredstvo koje laboratorija može sa pouzdanošću da koristi u proceni merne nesigurnosti, bilo kao trenutna zamena CRM, ili kao radni materijal laboratorije. $\mathrm{Na}$ ovaj način su prikazane korisne informaciji o mogućnostima različitih metoda određivanja merne nesigurnosti kao i različitih materijala primenjenih u laboratoriji za tehničku analizu ugljeva. Rezultati su pokazali da se, kako sertifikovani referentni materijali, tako i izabrani laboratorijski RM, može uspešno 
primeniti za procenu merne nesigurnosti tehničke analize ugljeva, a što je znatno jeftinije za laboratorijski rad, a u saglasnosti je sa standardnom normom ISO 17025.

\section{LITERATURA}

1] International Standards Organization, ISO/IEC 17025:2006, General Requirements for the Competence of Testing and Calibration Laboratories, ISO, 2006.

[2] Jovanović M., Acred. Qual. Assur. 2004, 9, str. 96-98.

[3] B. M. Simonet, Quality control in qualitative analysis, Trends Anal. Chem. 24 (2005), str. 525-531.

[4] Hubert Ph.; Chiap P.; Crommen J.; Boulanger B.; Chapuzet E.; Mercier N.; Bervoas-Martin S.; Chevalier P.; Grandjean D.; Lagorce P.; Lallier M.; Laparra M. C.; Laurentie M.; Nivet J. C. Anal. Chim. Acta. 1999, 391, str. 135-148.

[5] International Standards Organization, ISO/R 1928:1971, Methods of analysis of coal and coke. Determination of gross calorific value by the calorimetric bomb method, and calculation of net calorific value, ISO, Geneva, Switzerland, 1971.
[6] International Standards Organization, ISO/TS 12902:2001, Solid mineral fuels - Determination of total carbon, hydrogen and nitrogen - Instrumental methods, ISO, Geneva, Switzerland, 2001.

[7] International Standards Organization, ISO 589:1981, Methods of analysis of coal and coke. Determination of total moisture in hard coal, ISO, Geneva, Switzerland, 1981.

[8] International Standards Organization, ISO 1171:1981, Methods of analysis of coal and coke. Determination of ash, ISO, Geneva, Switzerland, 1981.

[9] International Standards Organization, ISO 562:1981, Methods of analysis of coal and coke. Determination of the volatile matter content, ISO, Geneva, Switzerland, 1981.

[10] International Standards Organization, ISO 334:1992, Solid mineral fuels Determination of total sulfur - Eschka method, ISO, Geneva, Switzerland, 1992. 